\title{
Retail Investor Attention, Foreign Investors and Crash Risk: Evidence on Indonesian Shariah-compliant Equities
}

\author{
Aang Kunaifi $1^{*}$, Geodita Woro Bramanti ${ }^{1}$, Muhammad Ibnu Sina Al Hanif ${ }^{1}$ \\ ${ }^{1}$ Department of Business Management, Institut Teknologi Sepuluh Nopember, Surabaya 60111, Indonesia \\ *Corresponding author.Email: aang_kunaifi@mb.its.ac.id
}

\begin{abstract}
This study analyzes how retail investor attention and foreign investors are related to stock price crash risk in shariah-compliant equities. Using quarterly data in Islamic stocks that listed on the Indonesian Capital Market during 2016-2019, we show that retail investor attention and foreign investors are negatively associated with stock price crash risk. The retail investor attention and foreign investors diminish stock price crash risk in shariah-compliant equities. In conclusion, the benefit of active attention that retail investor pay and increasing foreign investor mitigate crash risk in shariah-compliant equities
\end{abstract}

Keywords: Retail investor attention; Foreign investors; Crash risk; Shariah-compliant; Equity

\section{INTRODUCTION}

Stock price crash risk has been financial issue in asset pricing [1]. The sudden movement of stock price could cause losses to investors assets. Stock price crash risk is measured by skewness of firm-specific return distribution. The skewness distribution of return is not only caused by investor confidence and sentiment but also caused by economic effect. The investors sentiment will impact on financial market outlook and capital market index.

Indonesia Sharia Stock Index (ISSI) has been launched on May 12, 2011. ISSI consist of Islamic stock listed on Indonesia Stock Exchange (IDX). Islamic stock/ equity as an alternative investment class for all investors is growing rapidly [2], especially as an alternative to moslem investor to invest in shariah-compliant equity. But ISSI constituent have been updated every twice a year. The Islamic stock has been evaluated and can be enter and come- out to ISSI constituent. This re-selected procedure in Islamic stock makes uncertainty to investors in shariah- compliant equities.

Investors in shariah-compliant equity can be classified as a faith-based investor and conventional investor [3]. A faith-based investor selects stock based on religious beliefs [4]. Investment decision making with Islamic investing criteria have several challenges to choose the stock and arrange portfolio rebalancing [5]. Investors in shariah-compliant equities, especially for a faith-based investor, must be update and give more attention on their portfolio for not only keeping the stock return but also the shariah-compliant that must be considered to make decision making on investment. Investors in Islamic stock will not be worse by choosing Islamic stock rather than conventional ones [6].

Information availability and current stock price can express an market efficiency. Investors gather their information to make investment decision making by using internet information, This is a monitoring mechanism that investors usually do. This information 


\section{Procedia Business and Financial Technology}

Proceedings of the 2nd International Conference on Business and M anagement of T echnology (ICO N BM T 2020) - Part 2

focus can be reflect investor attention in stock information. Islamic markets analysis indicate high longterm efficiency but moderate short-term efficiency [7]. This type of efficiency anomaly can be used by investors to make information selection attention.

Individual investors may get moreattention about the company and may mitigate asymmetryproblem [1]. Mitigated asymmetry problems can be diminished by more information about the company, so more difficult and costly the manager of the company to hide company bad news/ information. Company information will be used by an investor to decide their investment decision making. When the investor has more information, it willreduce future crash risk. A study by Wen et al (2019) shows that higher retail investors' attention has a lower future crash risk.In another study expected that increasing investor attention indicated byincreasing the search volume index will predict higher stock prices. In other studies, it shows that increasing investor attention as indicated by an increase in the search volume index will predict higher stock prices [8]. In this paper, it helps to empirically test the relationship between retail investor attention effect on future stock crash risk in the shariahcompliant equity market in Indonesia. Another act for mitigating future crash risk is the external monitoring role. The external monitoring role can be conducted by foreign investors. Foreign investors have more resources and expertise to monitor the local firm [9]. Some research has been explained the relationship between the foreign investor and future crash risk, but some studies indicate inconsistent results. Foreign investors are positively relationship with future crash risk [10] [11]. Another study explains that foreign investors reduce managerial bad-news hoarding and diminish future stock price crash risk [9]. This study contributes to the literature testing by empirical testing the role of foreign investor on future stock price crash risk.

\section{RESEARCH METHOD}

To analyze the relationship between retail investor attention, foreign ownership, and stock crash risk, weselect Islamic stock as ISSI constituent that listed in IDX. The period of the sample is from quarter 12016 to quarter 2 2019. We exclude financial services firms and firm-quarter observations with missing information for the research variable. Our final sample includes 2,430 firm-quarter observations representing 307 individual firm. We also winsorize the continuous variable at the $10 \%$ and $90 \%$ level to mitigate the effect ofoutlier.

We construct a "negative coefficient of skewness" (NCSKEW) as stock-price crash-risk measurement.
Larger NCSKEW indicate larger stock price crash risk. Using firm- specific skewness weekly stock return based on time-series regression to get the weekly residual of regression $(\mathrm{Wi}, \mathrm{t})$. The weekly residual of regression is used to calculate NCSKEW with following formula:

$$
\begin{aligned}
& \text { итгитги } \mathrm{n}(\mathrm{n}-1)^{3 / 2} \sum^{\mathrm{n}} W^{3} \\
& =\quad \mathrm{t}=1 \mathrm{i,t} \\
& \mathrm{t} \quad(\mathrm{n}-1)(\mathrm{n}-2)\left(\sum_{\mathrm{t}=1}^{\mathrm{n}} W_{\mathrm{i},)_{\mathrm{t}}}^{23 / 2}\right.
\end{aligned}
$$

Where, $\mathrm{n}$ is the number observation on stock $\mathrm{i}$.

Retail investor attention proxy is the frequency of google searches for individual firm tickers quarterly manually collected in the google index. Foreign ownership is percentage of share held by foreign investor both institutional and individual. The individual foreign investor is percentage of share held by foreign individual. To examine the impact of retail investor attention and foreign ownership on stock price crash risk, we run the following regression model:

Crashriski, $\mathrm{t}=$ $\alpha i+\beta 1$ ReIT $i, \mathrm{t}-1+\beta 2 F O R I i, \mathrm{t}+\beta 3$ IFORIi, $\mathrm{t}+\varepsilon i, \mathrm{t}$

Where Crashriski,t is proxied by NCSKEW, ReITi,t-1 is retail investor attention, FORIi,t is the proportion of foreign investor number in firm at the last of the quarter and IFORIi,t is percentage foreign individual investor. Retail investor attention variables are one-quarter lagged from the dependent variable allowing us to predict future crash risk.

We test the both fixed effect (FE) and random effect (RE) models separately to check if regression coefficients are off. The Hausman test has confirmed that FE model is more appropriate thus this is our main model. The results of standard Hausman tests reject the null hypothesis of fixed-effects ( $\mathrm{P}$ value $0.0241<0.05$ ) and suggest that $\mathrm{FE}$ is likely to produce consistent coefficient estimates for all the regression models. Consistent with the result Modified Wald test, the time dimension in this study is too small so the heterogeneity issue cannot be handled. Feasible generalized least squares (FGLS) will be used to deal with the inherent problems of heteroscedasticity.

\section{RESULTS AND DISCUSSION}

\section{Descriptive statistics}

The analysis descriptive for the major variable used in the regression model reporting in table 1 . The mean of crash risk measure is -0.46452 and the standard deviation is 


\section{Procedia Business and Financial Technology}

Proceedings of the 2nd International Conference on Business and M anagement of T echnology (ICO N BM T 2020) - Part 2

0.863903, suggesting the variation in the negative conditional return skewness between-sample.

The mean and standard deviation of retail investor attentionis 4.585356 and 1.012089 respectively, indicates that the investor has more attention on Islamic stock. The average and standard deviation of foreign investors (individual foreign investors) is 0.340081 (0.003054), and the standard deviation of foreign investors (individual foreign investors) is $0.283942(0.005073)$, indicates that variation in foreign investors proportions in an Islamic stock among the sample.

Table 1 Descriptive statistics results

\begin{tabular}{cccccc}
\hline Variable & Obs & Mean & Std. Dev. & Min & Max \\
\hline NCSKEW $_{\mathrm{t}}$ & 2430 & -0.46452 & 0.863903 & -2.30213 & 1.468383 \\
ReIT $_{\text {i, }-1}$ & 2430 & 4.585356 & 1.012089 & 2.564949 & 6.291569 \\
FORI $_{\text {it }}$ & 2430 & 0.340081 & 0.283942 & 0.000645 & 0.884094 \\
IFORI $_{i, \mathrm{t}}$ & 2430 & 0.003054 & 0.005073 & 0.000000 & 0.02055 \\
\hline
\end{tabular}

\section{Regression analysis}

The result in table 2 indicates that retail investor attention is negatively relationship with one-quarter-a head crash risk. It is shown that NCSKEW have a significantly negative relationship with retail investors attention. The coefficient ReITi,t-1 is highly significant with an expected negative sign, -0.04142 with $\mathrm{t}=0.017$. This significantly negative relationship between retail investor attention and future stock crash risk, suggesting that more investor attention in a firm, the lower crash risk will be in the future.

Investors in Indonesian shariah-compliant equities have more attention because some investors -specially faithbased investor in Islamic stock- have specific criteria and have more attention in his portfolio. This investor characteristic is different between conventional equities that don't have this special investors characteristic. Investors attention is an external monitoring mechanism. Investor attention makes manager release public information. Monitoring mechanisms reduce information asymmetry and make managers tend to delay release bad information [12]. Highly retail investor attention giving more control and monitoring and make manager was challenging to keep the bad news. This mechanism suggests reduce future stock price crash risk.

Two different measures of the foreign investor in this study is using proportion on foreign investor of each firm and quarter and proportion of individual foreign investors each firm and quarter. The coefficient of FORIi,t indicates proportion on foreign investor of each firm and quarter. The coefficient of
FORIi,t is highly significant with and expected negative sign in crash risk. The regression analysis reported that the variable $I F O R I i, \mathrm{t}$ is highly significant with expected negative sign.

Table 2 shows the regression result. First, in the fixedeffects model, we regress the independent variable foreign investor against the stock price crash risk. We find that both foreign investor variable FORI and IFORI significantly associated with stock-price crash-risk measures. Moreover, consistent with these fixed-effect models, the FGLS models exhibit the significant mitigating influence of foreign investors on stock price crash risk by individual foreign investors. Our results reveal that foreign investor proxied by individual foreign investor mitigates stock price crash risk.

Foreign investors in Indonesian shariah-compliant equities have more carefully and using sophisticated analysis in investment decision making. Foreign investors role play external monitoring mechanism [9]. Foreign investors in Indonesian shariah-compliant equities can contribute more external mechanisms. This mechanism gives more monitoring incentives and diminishes future stock price crash risk.

\section{CONCLUSION}

We analyze the influence of retail investor attention and foreign investor on future stock price crash risk in Indonesia shariah-compliant equities. We find evidence of a mitigating effect of retail investor attention and foreign ownership on future stock price crash risk. Our result lends support to the notion that the investor plays an external monitoring mechanism effectively and reducing bad news by the manager.

Based on these study, retail investor in Islamic equities has to be more attention to Islamic stock with access the internet information as external monitoring to mitigate agency problems such as asymmetry information problem between retail investor, investment manager, and firm managers. This attention can avoid great lose in their portfolio investment. Another external monitoring can be contributed by foreign investor. Foreign investors have strong influence in stock price mechanism in Indonesian Islamic capital market. Although, the type of foreign investor in Indonesian Islamic capital market has a different role in detecting future stock price crash risk. This external monitoring mechanism can be relevant for the financial supervisory body to regulating, promoting, and attracting foreign investors in Indonesian Islamic capital market. 


\section{Procedia Business and Financial Technology}

Proceedings of the 2nd International Conference on Business and M anagement of T echnology (ICO N BM T 2020) - Part 2

Table 2 Panel data regression model for fixed effects regression (FE) and feasible generalized least squares (FGLS)

\begin{tabular}{cllll}
\hline Dependent Variable & \multicolumn{2}{c}{ Fixed-effects } & \multicolumn{2}{c}{ FGLS } \\
\cline { 2 - 5 }$N C S K E W_{\mathrm{t}+1}$ & Coef. & $\mathbf{P}>|\mathbf{t}|$ & Coef. & $\mathbf{P}>|\mathbf{z}|$ \\
\hline$R e I T_{i, \mathrm{t}}$ & -0.09505 & $0.005^{*}$ & -0.04142 & $0.017^{* *}$ \\
$F O R I_{i, \mathrm{t}+1}$ & -0.28618 & $0.091^{* * *}$ & 0.186526 & $0.003^{*}$ \\
$I F O R I_{i, t+1}$ & -17.9249 & $0.021^{* *}$ & -7.24801 & $0.038^{* *}$ \\
_cons $^{\text {cons }}$ & 0.123384 & 0.489 & -0.31591 & 0.000 \\
\hline
\end{tabular}

Note: $*, * *$ and $* * *$ denote 1,5 and 10 percent level of statistical significance.

\section{ACKNOWLEDGMENT}

This work was supported by Research of Business Management Department (Nomor: 1581/PKS/ITS/20 20).

\section{REFERENCES}

[1] F. Wen, L. Xu, G. Ouyang, and G. Kou, "Retail investor attention and stock price crash risk: Evidence from China," Int. Rev. Financ. Anal.,vol. 65, p. 101376 , Oct. 2019.

[2] B. Saiti, O. I. Bacha, and M. Masih, "The diversification benefits from Islamic investment during the financial turmoil: The case for the USbased equity investors," Borsa Istanbul Rev., vol. 14, no. 4, pp. 196-211, Dec. 2014.

[3] Z. Umar, "Islamic vs conventional equities in a strategic asset allocation framework," Pacific Basin Financ. J., vol. 42, pp. 1-10, Apr. 2017.

[4] O. Al-Khazali, H. H. Lean, and A. Samet, "Do Islamic stock indexes outperform conventional stock indexes? A stochastic dominance approach," Pacific Basin Financ. J., vol. 28, pp. 29-46, Jun. 2014.
[5] D. Ashraf and M. Khawaja, "Does the Shariah screening process matter? Evidence from Shariah compliant portfolios," J. Econ. Behav. Organ., vol. 132, pp. 77-92, 2016.

[6] L. Trabelsi, S. Bahloul, and F. Mathlouthi, "Performance analysis of Islamic and conventional portfolios: The emerging markets case," Borsa Istanbul Rev., vol. 20, no. 1, pp. 48-54, Mar. 2020.

[7] W. Mensi, A. K. Tiwari, and S. M. Yoon, "Global financial crisis and weak-form efficiency of Islamic sectoral stock markets: An MF-DFA analysis,' Phys. A Stat. Mech. its Appl., vol. 471, pp. 135-146, Apr. 2017.

[8] Z. Da, J. Engelberg, and P. Gao, "In Search of Attention," J. Finance, vol. 66, no. 5, pp. 14611499, Oct. 2011.

[9] J.-B. Kim, X. Li, Y. Luo, and K. Wang, "Foreign Investors, External Monitoring, and Stock Price Crash Risk," J. Accounting, Audit. Financ., p. 0148558X1984335, Apr. 2019.

[10] X. V. Vo, "Foreign Investors and Stock Price Crash Risk: Evidence from Vietnam," Int. Rev. Financ., Dec. 2018.

[11] J. W. Shin, "Foreign Ownership and Stock Price Crash Risk: Evidence from Korea,", Seoul, 2019.

[12] A. Habib, M. M. Hasan, and H. Jiang, "Stock price crash risk: review of the empirical literature," Account. Financ., vol. 58, pp. 211-251, Nov.2018. 